\title{
Synge med de dømte
}

Ingeborg Martens Lomholt Cand.phil., organist i Statsfængslet i Horsens 1975-2006

\section{Indledning ${ }^{1}$}

Gider du virkelig synge med kriminelle? Er det ikke spild af tid? Hvad får sådan nogle slyngler ud af det?

Sådan har folk spurgt mig gennem årene, for de syntes, at sang og fængsel ikke harmonerer. Jeg indrømmer, at det lyder som et paradoks, at fanger dengang som nu dyrker korsang i danske fængsler, når indespærringen grundlæggende opleves som pinefuld (Mathiesen:1989, Sykes (1958/2007)). Ganske vist kender mange fanger nogle af disse pinsler også udenfor, men i fængslet er de sat i system.

Bortset fra henrettelse og fysisk tortur ... er ingen straf så total, hvad angår ufrihed, nedværdigelse og demonstration af magt, som fængslet (Christie: 1996)

I dette essay undersøger jeg, hvorfor korsang er en afholdt fritidsaktivitet i fængslet og tager afsæt i en Musikkulturel Feltstudierapport (MF)«Synge med de dømte«, AU 2004. Her gør jeg rede for mit musikalske arbejde i Statsfængslet i Horsens (SH), hvor jeg, foruden at arbejde som organist og korleder i kirken, også var ansat som musiklærer i fængslets skole.

I indledningen af MF skriver jeg:

Det er min hensigt at feltstudierapporten skal afdække og analysere en musikalsk virkelighed på et, for mange mennesker, ukendt sted. Den vil undersøge, om beskæftigelse med levende musik kan være med til at styrke fangernes selvtillid, give dem nyt livsmod og gøre deres ensomhed mere tålelig, så de kan overleve i et lukket Statsfængsel.

\section{Metodiske overvejelser}

Med antropolog Kirsten Hastrups ord (Hastrup:1992) behøver etnografers vidensformidling ikke kun at dreje sig om geografisk fjerne folk, men kan lige så vel omhandle fjernheden i vores eget samfund. I denne forbindelse er et fængsel et fjernt sted for mange mennesker. Da det indsamlede materiale er

1. Tak til Inger Marie Fridhov for en interessant artikel i NTfK 3-2018, 'Klosteret' i Halden Fengsel - noe for seg selv 
skaffet til veje ved personlig tilstedeværelse midt i en specifik fængselsverden, benytter jeg mig af den antropologiske arbejdsmetode. Hastrup betegner feltarbejdet som en afgørende og dramatisk personlig erfaring, der giver stoffet liv:

Feltarbejdet skal ses som et møde, der forbinder oplevelse og metode i en samlet erfaring. Denne skal siden gøres til genstand for analyse og leverer i mange henseender den skjulte dagsorden for senere bearbejdning af materialet.

Subjektiviteten er på ingen måde en hindring for vores forståelse af andre kulturer, men derimod vores eneste redskab. Det er gennem den, at vi systematisk og refleksivt kan tilbagelægge afstanden fra det manifeste til det hypotetiske og nå en form for klarhed, der lader sig objektivere og flytte (s.27-29).

Ud fra disse metodiske overvejelser har jeg fra 28. februar til 1. april 2003 været deltagende observatør og nedskrevet feltnoter ${ }^{2}$ til brug ved rapportskrivningen. Essayet bygger på MF's afsnit om korsang, s. 5-16.

Både feltnoter, afsnit af $\mathrm{MF}$, korstemmer $(\mathrm{ks})^{3}$ og ikke mindst empiri fra mangeårigt korarbejde kaster fra alle sider lys ind på emnet, ligesom forholdet mellem kirkekultur og fangekultur, mellem indsatte og betjente og mellem kirken og ledelsen bliver observeret.

Ud fra Hastrups ord, at enhver kultur dramatiserer sig selv på en særlig måde, vil enkelte begivenheder blive tolket som betydningsfulde, da de peger ud over sig selv mod en større kulturel helhed. Lang tids medleven på stedet betyder, at jeg har været med til at forme, hvad jeg afdækker. Da jeg af fangerne blev objektiveret som hende med musikken, hun kommer fra kirken og er god nok, vil dette sammenfald af subjekt og objekt følge med ind i teksten (Hastrup, s. 34-39).

\section{Fængselskirken}

SH var Danmarks ældste aktive mandsfængsel. Det blev taget i brug i 1853 og nedlagt i 2006. Det var sikret med ringmur og i nyere tid tillige med såkaldt Nato-pigtråd og elektronisk overvågning. Fængslet var opført i fire etager, og inden for ringmuren fandtes værksteder, gårdtursareal og sportsplads.

Fængselskirken lå midt i bygningskomplekset. Der var højt til loftet og ingen tremmer for vinduerne, og den kaldtes flugtsikkert. For fangerne var kirken et fristed i fængslet. Her foregik alle kirkelige handlinger uden overvågning, så som gudstjenester, bryllupper og barnedåb.

Kirken havde egen præst og organist. For mit vedkommende betød det, at jeg skulle forholde mig loyalt over for ledelsen og ansatte uden at have

2. Jeg står inde for, at jeg levede op til de forskningsetiske krav, der var på det tidspunkt, hvor studiet blev gennemført. Jeg informerede det daværende kirkekor om feltnoterne og MF og interviewede to korsangere i anonymiseret form. De fik materialet til gennemsyn og godkendelse.

3. Korstemmer (ks) er udsagn af anonyme sangere (MF, forfatterens empiri, Kvist:2018) 
mundkurv på. Jeg var forpligtet på at følge et internt sæt regler med sikkerheden som afgørende faktor. Jeg havde tavshedspligt og skulle respektere de indsattes krav på anonymitet.

I dag er fængselskirken del af fængselsmuseet, men bruges stadigvæk til koncerter og enkelte kirkelige handlinger.

\section{Hvem meldte sig til korsang}

Det var oftest nyindsatte fanger, som meldte sig. Enkelte huskede sange fra deres skoletid, andre havde spillet eller sunget i et band. Jeg hørte vendingen Jeg synger kun når jeg er fuld, og for det meste stod jeg i et gabende tomrum, hvad dansk sangtradition angår. Flere koraspiranter tilhørte halvdelen af klientellet i Danmarks fængsler, som før indsættelsen havde haft et misbrug af alkohol, hårde stoffer, dopingmidler eller ulovlig medicin, der var medvirkende årsag til deres kriminalitet (Kriminalforsorgen, 2003).

Fanger med lange domme meldte sig, fordi de havde brug for at skabe sig et nogenlunde struktureret liv inden for murene. Gennem årene kunne jeg lære dem et bredt salmerepertoire, hvorved de dannede grundstammen i koret. Alle skulle gennem en stemmeprøve, for det var vigtigt, at de havde en tone i livet.

En dag meldte sig en ung fange med en dom på 14 år. Han ville gerne synge, men kunne ikke andet end brumme i et dybt stemmeleje. Han sagde Jeg kan ikke høre mig selv. Jeg gav ham en chance, og han fik enetimer sammen med en rutineret korsanger. Opgaven var, at brummeren skulle lytte til den andens stemme og derved finde sin egen. Først famlede han lidt, men så begyndte han at eftersynge tonerne. Ved hjælp af orglet øvede vi på en kendt salme i et dybt toneleje og gik trinvis op, så tonehøjden nærmede sig salmernes. Han blev forbløffet over at finde sin egen sangstemme og var i flere år medlem af korets basgruppe.

\section{Deltagelse og fravær}

Vi øvede fredage, lørdage og kort før søndagsgudstjenesten, ikke kun for at få salmer og korsatser på plads, men:

... weekenderne bliver nemlig ofte et mareridt af fri tid, som man selv må søge at 'få til at gå. I fængslet skal tiden helst ikke opleves, men umærkeligt forsvinde, indtil porten atter åbner sig ... (Kyvsgaard: 1989)

Fredagens korprøve begyndte ofte uroligt, fordi sangerne fysisk og mentalt skulle bevæge sig fra en støjfyldt afdeling til kirkens område. Arbejdsugen var slut, weekenden nærmede sig og personalet uddelte post og afleverede 
beskeder. Fangerne havde fortalt mig om deres frygt for, at kæresten i sidste øjeblik aflyste sit weekendbesøg. I sådanne øjeblikke var der uro og stress på afdelingen, som kunne ende i et skænderi mellem fange og betjent eller mellem fangerne indbyrdes. Man var nødt til at leve tæt på andre, som man ikke selv havde valgt og ikke kunne trække sig tilbage fra.

Men når koret efter telefonkontakt med personalet blev bragt til organistkontoret, slappede vi af med en kop kaffe og lidt kage. De første vittigheder fløj gennem luften, men privatlivet holdt man for sig selv. Venskaber mellem fanger var sjældne, og selv en såkaldt kaffemakker var ikke til at stole på, hørte jeg en korsanger sige.

En gang imellem nægtede en sanger at komme, som det skete en fredag under feltnoteskrivningen. Dagens korprøve var usædvanlig, fordi den blev optaget af et filmhold. ${ }^{4}$ Jeg skrev:

der kommer kun seks ud af 11 mænd. Af sikkerhedsmæssige grunde må en enkelt korsanger ikke deltage, og en anden vil nok synge med, men ikke filmes. En sanger er på orlov, en anden syg; den sidste gider ikke komme, da han lige fra sengen om morgenen blev visiteret for stoffer.

Mens orlov, sygdom og sikkerhedsmæssige forhold var kendte grunde, signalerede sidstnævnte fange, at morgenens visitation føltes som et overgreb. De svin ville bare stresse mig, råbte han ved næste korprøve. Visitationer $\mathrm{i}$ fængslet var del af hverdagen, og derfor havde jeg aldrig muligheden at forudsige, hvordan en korprøve ville gå. Men måtte få det bedste ud af det, som omstændighederne nu bød.

I en anden feltnote skriver jeg, hvordan en stofmisbruger, som var sanger og guitarist i koret, reagerede, da vi skulle medvirke ved en TV-udsendelse:

KI. 15.45 ankommer TV journalisten til porten, hvor jeg har meldt hans ankomst. Efter en kort briefing og et interview kalder jeg på koret, som er på 8 medlemmer. Korets guitarist forlader stedet umiddelbart efter, angivelig på grund af voldsom hovedpine. Han viser sig ikke siden.

Selv om guitaristen og jeg havde talt alt igennem til mindste detalje og øvet kort forinden, glippede det altså. Verden kom for tæt på, og heller ikke jeg kunne tage angsten fra ham og han løb i panik.

Hans angstfyldte reaktion var ikke usædvanlig og en typisk følge af mange års misbrug. I fængslet afskærmede mange stofmisbrugere sig fra omverdenen ved at leve som under en glasklokke. De fortalte, at de så frem til aftenens indelåsning. Ikke sjældent isolerede de sig frivilligt, oftest på grund af gæld ${ }^{5}$

4. Dokumentarfilm SLOTTET (2003) af Jørn Kjær Nielsen

5. MFs. 13 


\section{Vi synger}

Ks: Korsang er for mig som en strafafbrydelse, som en dyb vejrtrækning så man kan holde til en uge mere herinde

Det smukke kirkerum åbnede sig, når vi begyndte på korprøven. Vejrtrækningsøvelser blev afløst af stemmetræning, hvor krop og sind blev aktiveret. Når vi åbnede kormapperne, løftede stemmerne sig. Koret holdt af sange, som duftede af frihed og kærlighed, og indimellem lærte vi en ny sang eller spiritual, som vi hurtigt tog til os og kom til at holde af.

Ks: i kirken kan man bedre få luft, end andre steder i fængslet, - når det hele er surt og træls, har jeg fundet en oase ved at synge

Når fangerne ønskede sig sange, valgte de ikke sjældent Papirsklip, HS 1396 eller Der er så meget, som kan trykke, HS 141. Fra et hårdt miljø i og uden for fængslet var de fortrolige med sangenes grundmotiv af håbløshed og kulde, hvor drømmene tager over:

Når nu min verden bliver koldt og forladt, finder jeg trøst i min kæreste skat, klipper motiver med drømme og saks, papirssilhouetter af den fineste slags.

Foruden ovennævnte sange kunne et typisk repertoire fra årene 1998 - 2006 være:

Amazing Grace - Spiritual HS 74

And so this is Christmas HS 246

Barndommens land HS 134

Den blå anemone HS 262

Der er i dag et vejr, et solskinsvejr HS 266

Forlad os vor skyld HS 105

Friheden flyver HS 198

God morgen, lille land HS 30

Herre, vi råber alle til dig - Spiritual

I skovens dybe, stille ro HS 572

Jeg drømte om atten svaner i nat HS nr. 449

Kvinde min, jeg elsker dig, Kim Larsen »Gas 5« 1975

Let it be - HS 121

Marys boychild - Spiritual

Ks: det føles som at være på højskole-man glemmer helt, at man er i fængsel

Mens fredagens sange var afholdte og genkendelige, havde vi brug for koncentration, når søndagens salmer skulle indøves om lørdagen. Salmesang er jf. den danske Folkekirkes lutherske selvforståelse del af forkyndelsen, og da koret havde forsangerfunktion, skulle hver korsanger helst kende søndagens salmer. Vi indlærte vanskelige melodier, gennemgik uforståelige tekster og opfriskede gudstjenestens ritualer, hvoraf enkelte blev sunget tostemmigt (tenor/bas).

6. Højskolesangbogen, 18. udgave 
Korsangerne kom til at holde af livsbekræftende salmer som Se nu stiger solen af havets skød (DDS nr. 754) og Herre Gud! Dit dyre navn og ære (DDS nr. 7). ${ }^{7}$ Da kunne de opleve øjeblikke af intensiv glæde, og for enkelte blev kirken stedet for Guds kærlige nærvær.

Også salmen »Guds kærlighed er strand og gronne enge« (De Unges Sangbog nr. 226) taler til fangerne med dens udsagn om fængsel og frihed, om dom og tilgivelse. Ordene tilsiger, at livet ikke kun består af tilfældigheder, der udviklede sig katastrofalt, sådan som fanger kunne prøve at forklare deres forbrydelse. Der findes stadigvæk et håb, og selv om de er udstødt af samfundet for en tid, er de dog elsket af Gud. ${ }^{8}$

Ks: når vi synger salmer, så ved vi, at de altid ender godt, at Gud altid holder med os.

For os herinde er det jo endt skidt, men måske kan det vende.

I en vis forstand handler musikken om å fargelegge øyeblikk og hendelser i livet med følelser, om å produsere gjenstander og relasjoner til tid og sted slik at verden ikke framstår tilfeldig og uten hensikt for oss. Disse hendelser og tildragelser blir tilstedeværende som betydningsfulle, de blir ladet med kraft, verdier, emosjoner og stemninger«. (Ruud: 1997, s.57) Vi sang gerne Davids salmer og lovsange (Tillæg til DDS: 1994) og i en feltnote noterer jeg:

... vi øver på salmen »Fra det dybe råber jeg til dig, Herre« (Nr. 921). Sunget i enstemmighed høres den som et fælles nødråb og gyldigt udsagn fra de indespærredes dyb.

Nogle korsangere med lange domme var forankret i kristendommen og fortrød bittert deres kriminalitet. For dem var kirken et livsnødvendigt anker, hvor nadverens syndsforladelse holdt fortvivlelsen fra døren. Således kunne drabsmandens sorg over sin forbrydelse være meget håndgribelig (Leer-Salvesen:1988).

\section{Vi er en gruppe}

Edgar H. Scheins kulturbegreb (1986) vil blive anvendt til belysning af korgruppens kultur.

Han inddeler kulturen i tre niveauer: kultursymptomer, kulturværdier og kulturens grundlæggende antagelser.

Det fundamentale træk ved kultur er grundlæggende antagelser og overbevisninger, som er fælles for medlemmer af en given gruppe. I et forsøg på

7. Den Danske Salmebog 2003.

8. MF s. 11 
at overleve i dens eksterne miljø samt for at løse interne problemer, har de gjort sig nogle fælles erfaringer. Hvis

disse erfaringer har vist sig at være positive, er de blevet gentaget, og er dermed langsomt blevet omdannet til ubevidste og almengyldige antagelser.

I forbindelse med korets kulturelle udviklingstrin anvender jeg E. H. Scheins gruppeudviklingstanker. Her inddeles en gruppes udvikling i fire stadier, hvor første stadie kaldes jeg-orienteret med emotionel vægt på den enkeltes rolle i forhold til de andre. Gruppens dominerende antagelse er: Lederen ved, hvad vi skal gøre. I andet stadie er fokus flyttet fra den enkelte til gruppen. Medlemmerne er fusioneret, og det emotionelle mål er harmoni, konformitet og nærvær med den dominerende antagelse, at vi kan allesammen lide hinanden. Stadie tre har effektivitet og gensidig accept som grundlæggende antagelse, mens det fjerde taler om gruppens modenhed.

Disse tanker kan kun med forbehold anvendes i en gruppe, som lever i en totalinstitution, hvor pludseligt fravær og hastige fangeflytninger var daglige hændelser. Interne straffe med ophold i strafcelle kunne også ramme korsangere, og da var det svært, at fastholde og udvikle en decimeret korgruppe.

Derfor blev første stadie korets faste holdeplads ud fra den grundlæggende antagelse, at lederen ved hvad vi skal gøre. Supplerer man med antagelsen Lederen er på vores side, var dette korets mest fundamentale kulturtræk og grundlæggende antagelse. Man stolede på korlederen og regnede med hendes hjælp, når der var problemer. ${ }^{9}$

\section{Korlederrollen}

Nogle handlemønstre og egenskaber viste sig at være værdifulde, når man var korleder for fanger i en totalinstitution:

\section{Man skulle være veloplagt og lydhør, være tålmodig og ikke spare på roser. Man måtte være fleksibel og forstå at manøvrere i et usikkert farvand}

For mit vedkommende var nogle egenskaber medfødt og handlemønstre tillært gennem et mangeårigt fængselsarbejde. Min umiddelbare tilgang til korgruppen var båret af accept, anerkendelse og fælles glæde ved musikken. Jeg lod mig gerne belære af fanger, som havde teknisk viden angående rockinstrumentariet eller kendskab til de fedeste rockgrupper.

Set med kritiske øjne kunne min ledelsesstil ind imellem være inkonsekvent:

Ks: hun roste os, men alligevel er hun ikke tilfreds

9. MFs. 10 


\section{Korskjorten som identitetsmarkør}

Korets hvide skjorter, påtrykt kirkens logo, spillede en vigtig rolle for gruppeopbygningen. De var tegn på sangernes tilhørsforhold til korgruppen og styrkede deres musikalske identitet. Da indsatte i offentligheden ofte bliver defineret ved deres forbrydelse, signalerede skjorterne en helt anden side, som har med bløde værdier som sangglæde og kreativitet at gøre. Skjorterne var en donation, da vi savnede en fælles påklædning i en TV-udsendelse. ${ }^{10}$ En sanger ansøgte et kendt tøjfirma, om at sponsere skjorter til kirkekoret. Ønsket blev endda opfyldt med to skjorter til hver sanger.

\section{Musikalske besøg}

Når koret mødte udefra kommende kor eller solister, kunne der opstå et ligeværdigt forhold omkring musikken, hvor Jeg-orienteringen blev udvidet til gruppeansvarlighed og gensidig accept under mottoet: vi er alle i samme båd, vi er alle nødt til at bidrage til gruppen, jf. stadierne to og tre.

Det skete eksempelvis, når koret sang med solisten Susie. Hun kendte fængslet indefra, da hun tidligere havde været medlem af et ungdomskor, som i mange år kom i fængselskirken og sang De 9 læsninger, en adventsgudstjeneste efter engelsk tradition. Kirkekoret plejede at medvirke, og enkelte langtidsfanger kendte hende derfra.

Én søndag sang vi Deep River med Susie og i en feltnote skrev jeg, hvad fangerne lidt for sjov sagde: „Hvordan var det nu, man taler til en pæn pige? Man bander vist ikke ${ }^{11} \mathrm{Jeg}$ begyndte i god tid at øve med koret, da alt, som afveg fra normal procedure, kunne skabe forvirring og uro. Vi gennemgik sangens engelske tekst, og bas- og tenorgrupperne lærte deres stemmer. Lørdagen før kom Susie, og korsangerne havde klædt sig pænt på. Efter den første forlegenhed indfandt koncentrationen sig, og stemmerne fandt hinanden efterhånden til en velfungerende Gospel.

Ved søndagens gudstjeneste sang vi Deep River som postludium. I kirkerummets fine akustik hævede kvindestemmens lyse klang sig smukt over mandsstemmernes mørke bund. Nede fra kirkebænkene lød klapsalver, og koret rankede sig.

10. DR1 1998: Vers og viser om Vorherre

11. I et mandsfængsel kunne forholdet til kvinder være anspændt, selv om der var ansat kvindelige fængselsbetjente, som var dygtige og respekteret af fangerne. Men de var del af et forhadt system. 


\section{Korhierarki og udstødelse}

For at tegne et helt billede, må baggrunden for det kulturelle drama med, for det er i spændingsforholdet mellem de mærkede og de umærkede hændelser, at nøglen til indsigt findes - der er grænser for, hvor tæt på den anden virkelighed, vi kan komme. Der vil altid være en grænse, der ikke kan overskrides (Hastrup: s. 32,33)

Fanger med lange domme var en slags kirkelige kulturbærere. Midt i korets mange udskiftninger videregav de kulturelle adfærdsmønstre, der knyttede sig til det kirkelige rum, som respektfuld optræden, pligtopfyldelse og pålidelighed.

Ks: I kirken er man nødt til at ligne et menneske hver søndag. Her er der takt og tone. Man opfører sig anderledes end i dagligdagen. - Kirken er for mig, hvor orgelet står. Der er lyden og atmosfæren, men det er ikke noget med tro.

De havde tilegnet sig en grundlæggende viden om salmer og kirkelige ritualer, som de videregav til nye sangere. I koret fandtes en orden, hvor den af de kulturbærende fanger, som havde sunget længst tid i koret, overtog en ledende rolle. Det kunne helt konkret aflæses af hans placering, idet han stod tættest ved orglet og bad ind- og udgangsbøn ved gudstjenesten. Der var rift om pladserne tættest ved orglet, som kunne minde om jalousi, men der blev ikke talt om det.

Min holdning blev sat på prøve, når enkelte, kulturbærende korsangere ligefrem smed en stofmisbruger ud af koret. De var få og tilhørte et forstærket socialt hierarki blandt fanger, ${ }^{12}$ hvor stofmisbrugerne er dem, der rangerer lavest. Denne konstellation viste sig også i koret.

På et tidspunkt havde jeg optaget en fange i koret med en smuk stemme. Han var også en god guitarist - men han var aktiv stofmisbruger. Og efter kort tid forsvandt han. Da jeg spurgte koret, hvor han blev af, var svaret: han gad ikke være med længere. Da jeg kort efter besøgte ham i cellen, sagde han: de truede mig og sagde, at jeg bare skulle fise af. Og han bad mig tie om det.

Ved næste korprøve orienterede jeg koret, at jeg ville beholde sangeren. Og at det selvfølgelig var mig som korleder, som valgte nye sangere. Lederen af de kulturbærende korsangere sagde bare:

Han sniffer heroin om natten, og vi gider ikke kigge på ham søndag morgen, - han lugter og ligner et lig. Men hvis du vil beholde ham, så går vi.

Enkelte i koret tav, men alligevel blev det de indbyrdes sociale lovmæssigheder fangerne imellem, der afgjorde sagen.

Hele mit korarbejde ville gå i stykker, hvis jeg satte min vilje igennem. Jeg var i et dilemma mellem fangernes kultur og mine egne værdier. Mange gange

12. Socialstyrelsen 2012:Veje ind og ud af kriminalitet, NIRAS konsulenterne, s. 92-93. 
kendte jeg ikke den reelle baggrund, men mærkede dog, at der var penge

i klemme eller at vedkommende havde overtrådt uskrevne fangeregler. Her var en gråzone, som jeg ikke var del af, og under protest måtte jeg bøje mig og samtidig opleve rystelsen over at blive udfordret på både menneskesyn og selvforståelse. - Det skal tilføjes, at mange af de indsatte skelnede skarpt mellem brug af hårde stoffer og en pibe hash. Denne var accepteret af de fleste, og selv betjentene lukkede øjnene, for så var der ro på afdelingen. Men fik man en bøde, tog man den, som den kom.

Stofmisbrugeren isolerede sig efterfølgende, men jeg musicerede stadigvæk med ham. Han var bare ikke længere med i korets fællesskab, og det var en bitter kendsgerning.

\section{Samarbejde med fængselspræsten}

Jeg havde et godt samarbejde med fængselspræsten, som også er min ægtefælle. Vi var civile i et uniformeret univers og delte kirkelivets glæder og besværligheder i fængslet.

Ved gudstjenesterne var kirken et troens rum med præstens forkyndelse, korets sang og orglets toner. Kirkegængerne respekterede gudstjenestens gang, men der blev snakket i kirkebænkene, og få sang med på salmerne. Alle satte dog pris på et frit sted, langt fra magtanvendelse og overvågning.

\footnotetext{
... mennesket i straffen, som vi kender det, har aldrig færdedes i kirkelige cirkler. Det er fuldstændigt ukendt i den verden. Når fangerne kom i kirken, var de temmelig fremmede over for gudstjenesten. Måske kom de for der at finde et fristed, et åndehul - midt i omgivelser, hvor man ellers fra alle sider føler sig iagttaget, overvåget og underlagt tvang (Lomholt, Forbryderalbum, s. 116)
}

Præsten brugte sit kontor til sjælesorgssamtaler, men det skete også, at han talte med fanger $\mathrm{i}$ kirken, når de ønskede det.

Også jeg brugte kirken til at musiktimer med fanger og plads til fortrolige samtaler. Det skete eksempelvis, da en nyindsat ung fange med 16 år i dom gerne ville lære at spille på harmonika. Men han trængte også til at fortælle om sit liv, som havde taget en fatal drejning, der bragte ham mange år i fængsel.

Præst og menighed, samt organist og kirkekor kom dog på en hård prøve, da påskegudstjenesten i år 2000 pludselig blev afbrudt af en razzia. Her oplevede vi, at kirken blev stormet af betjente, som på ingen tid tog både kor og menighed med sig til kropsvisitation, mens andre gennemsøgte kirke- og orgelrum. Her viste fængselsregimet sin hensynsløse, kontrollerende magt ved at bryde ind i kirken under påskegudstjenestens nadverfejring. Således kunne rammerne omkring koret være uforudsigelige og en sjælden gang kaotiske.

Samme dag sendte fangernes fællestalsmand og fængselspræsten en skarp klage over aktionen til fængslets ledelse. Fangernes ret til religionsudøvelse 
blev krænket, da de blev ført til visitation, før den kirkelige handling var afsluttet.

Der gik over to år, hvor aktionens rapport angiveligt var bortkommet og siden fundet igen. I sidste ende afviste ledelsen klagen, idet man kaldte aktionen en visitation på baggrund af begrundet mistanke om besiddelse af ulovlige effekter/rusmidler, selv om man fandt intet. Men måden, hvorpå den ansvarshavende vagtmester gennemførte aktionen, blev kritiseret af fængslets ledelse, som fremgår af en intern meddelelse fra fængselsinspektøren til Direktoratet for Kriminalforsorgen (DfK). Her står bl.a.: ... med begivenhederne i mente burde visitationen ikke have været gennemført på den måde, som tilfældet blev. ${ }^{13}$

Vel handlede de deltagende betjente efter ordre, men spændingerne mellem dem og kirken var tydelige. Blandt det uniformerede personale gik rygtet om handel med euforiserende stoffer under gudstjenesterne, selv om præst og organist tog skarp afstand fra det, idet trafik med illegale stoffer forekom overalt i fængslet og kunne også ske i kirken. Men det kirkelige område var ikke bevogtet under gudstjenesterne, hvorfor mistænkeliggørelsen lå nær. Kirken var sårbar, og denne præmis måtte præst og organist leve med. ${ }^{14}$

\section{Korsang i Norden og i Danmark}

Efter en systematisk undersøgelse af alle fængsler i Sverige og Norge igennem deres respektive hjemmesider, har jeg konstateret, at der ikke findes oplysninger om korsang. Derimod er korsang fortsat et almindeligt fritidstilbud i danske fængsler. Såvel Kriminalforsorgen som ledelsen i de enkelte fængsler ser for det meste positivt på denne aktivitet. ${ }^{15}$

I 2019 interviewer jeg fængselspræsten og organisten på Enner Mark Fængsel (EMF). Begge fortæller om nedsektioneringer af afdelinger, for at holde kriminelle bander adskilte. Derfor må kirken holde flere gudstjenester for små grupper. Organisten har flere kor, både for fællesskabsafdelingen, kontraktog behandlingsafdelingerne og små gudstjenestegrupper. Ved alle kirkelige handlinger er vagtpersonale til stede. Præst og organist taler om gode fællesskaber omkring kirken, hvor man manøvrerer i et system, der stiller store sikkerhedskrav.

13. Jfr. fængselsinspektørens skrivelse fra juni 2002 til Justitsministeriet og DfK/191161-1445

14. ...vi kan og vil ikke have nogen kontrolfunktion i kirken... Carl Lomholt i "Hilsen fra Statsfængslets kirke" juli-august 2000

15. Jeg var i kontakt med fængselspræster og organister i lukkede og åbne fængsler i DK. Alle bekræftede at der fandtes større eller mindre kor på deres arbejdsplads 


\section{Farvel til Slottet}

I slutningen af 2006 lukkede Statsfængslet i Horsens, og de fleste fanger blev flyttet til det nybyggede og højsikre EMF. I foråret samme år lavede jeg en indspilning med kirkekoret og en flok musikalske gæster ude fra. Vi ville synge et farvel til stedet, som havde rummet så megen sorg og smerte, så mange drømme og bristede forhåbninger. Cd'en fik navnet Farvel til Slottet. ${ }^{16}$

Koret havde fået flere medlemmer, og enkelte sangere kunne synge solo. Vi havde opbygget et repertoire, som vi ved små interne koncerter præsenterede for kirkefolk fra nærområdet. En langtidsfange i koret havde under afsoningen bygget strygeinstrumenter, som ved hjælp af professionelle musikere skulle medvirke ved indspilningen (Strube 2011:Violinbyggeren).

Før vi begyndte at øve, talte jeg med koret om mødepligt og ansvarlighed. Projektet betød et indgreb i fangernes privatliv, da der ventede intensive korprøver og lange indspilningsdage. Selv om fangerne måske hellere ville spille kort, ryge en joint med makkeren, lave mad eller bare sove, skulle de møde op til hver eneste prøve.

Da vi mødtes til første prøve, manglede en sanger. Den uheldige var om natten blevet flyttet til Vestre Fængsel på grund af et farlighedskriterium. Vi andre begyndte at arbejde med sange og tekster. Selv om enkelte i koret sagde:

\section{Ks: Jeg kender sangene, jeg behøver ikke at øve mere}

mødte alle op, på nær én. Midt i forløbet nægtede han at fortsætte projektet. Han var øverst i fangernes hierarki og sagde: det her er jo en ren børnehave. Jeg fik refereret, at en lille korgruppe trak ham til side og sagde til ham:

Ks: Vores korleder er gammel og går snart på pension. Vi kan ikke være bekendt, at cd-projektet går i vasken

Måske var den strenge mødepligt blevet for meget for den såkaldte udbryder, måske var han sur, fordi hans høje, hierarkiske status for en tid var sat på pause. Men han lod sig overtale af kammeraterne og fortsatte.

Ks: Sammenholdet var det bedste, vi indtil nu har haft, helt sikkert fordi vi kun havde én opgave, - at gøre det så godt vi kunne

Indspilningen fandt sted i fængselskirken med dens fine akustik og strakte sig over en hel weekend. Tekniker og producer havde indtaget deres rum. Ledninger og højtalerstativer var på plads, og musikere og kor udefra indfandt sig. Korsangerne mødte fuldtallige op både lørdag og søndag, hver gang ca. 8 - 10 timer. Opgaven greb dem, og der var ingen sure miner eller højrøstede

16. Statsfængslet i Horsens hed i folkemunde 'Slottet' 
beklagelser. En sanger betroede mig, at han havde sat »stofferne på hylden« i denne weekend, for at være klar i hovedet.

Ks: der var jo topprofessionelle mennesker omkring os og der gik sport i det. Nogle gange sagde koret selv, at vi gerne ville synge en sang om igen - vi blev grebet af det alle sammen.

Ros eller ris blev leveret kontant af korleder og producer, og efter mange rettelser og gentagelser kom sangene og musikken på plads. Da jeg bagefter mødtes med sangerne, sagde én af dem:

Ks: Under cd-optagelserne følte jeg mig som et ligeværdigt menneske. Vi talte sammen i en kærlig tone og ingen så skævt til os fanger. Det kender vi ellers ikke herinde ...

Det blev en smuk non profit-indspilning og al overskud ved salg doneres til SAVN,${ }^{17}$ en organisation, som støtter fangernes børn og familier i Danmark.

\section{Konklusion}

Korsang blev for mange fanger en hjælp til at overleve et lukket fængsels pinefulde begrænsninger. Den var en her og nu oplevelse, langt fra fængselspolitiske tanker om rehabilitering. Måske virkede korsang rehabiliterende, men så var det en ekstragevinst og ikke dens begrundelse.

I SH var korets hovedfunktion knyttet til kirken, som var et frirum for de indsatte, langt fra personalets kontrol og afdelingens stressende liv. I kirken var fangerne mennesker og ikke et nummer på en celledør. De fik luft for vrede og frustration og trak vejret dybt for livsmod og håb. Her turde man vise en følsom side af sig selv, som ellers blev gemt langt væk. Selvtilliden voksede, når sangerne følte sig ligeværdige ved musikalske besøg udefra.

En brummer uden stemme begyndte at kunne høre sig selv og blev en habil bassanger. I sandhed et lille mirakel for ham og os andre. Korprøver, gudstjenester og en kop kirkekaffe afbrød weekendens mareridt af tid og ensomhed.

Selv om arbejdet med koret byggede på et tillidsfuldt forhold mellem sangere og dirigent, måtte jeg leve med flere dilemmaer, hvor jeg måtte manøvrere mellem fangekultur og fængselskultur, mens mit ståsted var kirkens kultur, hvor solidaritet med de svageste var forankret i mit kristne menneskesyn. Når jeg overtrådte fangekulturens regler, kunne jeg tabe kampen og blev smertelig bevidst om mit svigt.

I Argumenter for benådning (Seeberg:1976, s. 9-10), ansøger en hel by dommeren i landsretten om øjeblikkelig frifindelse af en mand, der er anklaget for flere mord. Byen anfører som argument, at den anklagede under ingen omstændigheder kan undværes i byens enestående mandskor, hvor han syn-

17. www.savn.dk 
ger den dybeste bas, som udgør sangens mørke grundlag. Byens bøn til dommeren er: Giv os den anklagede fri for sangglædens skyld, for musikken er større end forbrydelsen. I dette metaforiske udsagn skjuler sig en kærne af sandhed, som også fik mund og mæle i Statsfængslet i Horsens. Også her blev musikken større end forbrydelsen, når korets bevægende sang lød bag murene.

Kontaktoplysninger

Ingeborg Martens Lomholt: ingeborg.lomholt@stofanet.dk

\section{Litteratur}

Nils Christie: Kriminalitetskontrol som industri. Hans Reitzels Forlag 1996

Kirsten Hastrup: Det antropologiske projekt - om forbløffelse. Gyldendal 1992

Direktoratet for Kriminalforsorgen (2003): Sundheds-og AEldreministeriet, afsnit 7: kampen mod rusmiddelmisbruget

Fængselsshoppen, Fængslet, Fussingsvej 8, DK-8700 Horsens: 'Farvel til Slottet', cd med fangekoret i Horsens 2006

Dorte Kvist i samarbejde med Carl og Ingeborg Lomholt: Det er jo mennesker. Eksistensen 2018

Britta Kyvsgaard: ..og fængslet ta'r de sidste. Jurist- og Økonomiforbundets Forlag 1989 Ingeborg M. Lomholt: Musikkulturel Feltstudierapport (2004), httpS//www.aau.dk. Institut for AEstetiske Fag, afdeling for Musikvidenskab. Uudgivet

Thomas Mathiesen: Kan fængsel forsvares? Socpol 1988

Even Ruud: Musikk og Identitet. Universitetsforlag Oslo 1997

Edgar H. Schein: Organisationskultur og ledelse, København 1986 i Kompendium til Institutions-/organisationsanalyse v. Henrik Kaare Nielsen. AEstetik og Kultur 2002

Peter Seeberg: Argumenter for benådning, noveller. Gyldendals Tranebøger 1976.

E. Skærbæk \& E. Stabrun: Forbryderalbum, Alternative fængselsbilleder. Socpol 1988

Henrik Strube: Violinbyggeren. Lindhardt og Ringhof 2011

NIRAS Konsulenterne: Veje ind og ud af kriminalitet. Socialstyrelsen 2012 